\title{
Social Media Success for Knowledge Sharing: Instrument Content Validation
}

\author{
Setiawan Assegaff ${ }^{1}$, Kurniabudi $^{2}$, Hendri $^{2}$ \\ ${ }^{1}$ Information System Postgradute Program, Dinamika Bangsa Computer College, Indonesia \\ ${ }^{2}$ Departement of Computer Science, Dinamika Bangsa Computer College, Indonesia
}

\section{Article Info \\ Article history: \\ Received Mar 21, 2016 \\ Revised Jul 11, 2016 \\ Accepted Jul 27, 2016 \\ Keyword: \\ Social Media \\ Knowledge Sharing \\ IS Success Model \\ Content Validation \\ Academic}

\begin{abstract}
Knowledge sharing is important activity for create a new knowledge. Information technology today brings big oppurtubity for people in conduct knowledge sharing. This media provides effective and competitive technology tool for knowledge sharing. The aimed of this study is to report the on process research that investigates the success of social media for sharing knowledge among scholars in Indonesia. This study focus to discuss the instrument development stages from the research especially discuss how content validity conduct for in instrument validation progress. Method for content validation progress was adopting from Beck and Gale approach in nursing area. This study resulted in a validated instrument from content validation approach.
\end{abstract}

Copyright (c) 2016 Institute of Advanced Engineering and Science. All rights reserved.

\section{Corresponding Author:}

Setiawan Assegaff,

Information System Postgraduate Program,

Dinamika Bangsa Computer College,

Jl. Jend. Sudirman, Thehok, Jambi, 36138, Indonesia.

Email: setiawanassegaffl@stikom-db.ac.id

\section{INTRODUCTION}

Knowledge Sharing (KS) is regarded as a process that is vital in an organization, this is because KS is the foundation of the birth of new ideas, a forum for the development of business innovation and implementation of a learning process for workers [1]-[5]. Nonaka (1994) defines KS as an activity designed to help people work together, facilitating the exchange of knowledge between employees, increasing the learning capacity of the organization, thereby increasing the ability of people and organizations reach their goals. Furthermore KS is believed to improve the organization's values due to dissemination of knowledge among employees [3].

The examples of simplest KS activities are the willingness of an employee to establish communication with his colleagues, and actively consult to learn from them. KS can take place either at the level of the individual or organization. KS individual level through dialogue between individuals intended to make employees work better, faster and more efficiently. While at the organizational level, KS refers to how organizations to capture, document, organize, reuse, and transfer the knowledge/ experience based knowledge is organized, and make knowledge available and accessible to all members of the organization within the company. Due to the role of supervisors is so important in an organization; the organization trying to KS can run well. Previous research has identified that organizations that successfully promote KS culture not only because the organization successfully synergize utilization of knowledge in its business strategy, but also how the organization is able to intervene/ changing the attitudes and behavior of workers to be willing and consistently participating in KS.

Currently, the development of information technology has provided many new opportunities so that the exchange of knowledge can be accomplished even if constrained by distance, time and place [6]. Through 
a variety of applications and new technologies of information technology can be used as a solution for the above problems. One promising technology is by using social media facilities. With all its social media can be utilized as much as a virtual tool that can help in communication, interaction, and collaboration or virtually [7]-[9]. Features such as chat feature, Facebook wall, sharing documents, and video conferencing are some of the facilities that can be utilized in the sharing of knowledge among members of a group in social media. Not only in terms of features, the amount of use of a large social media is also a tremendous potential [7].

Research in the field of social media and KS that has done this time includes conceptual models, case studies, empirical studies (e.g., [10]-[16] One of the studies related to the social media and KS by Razmerita et al. (2009)). They argue that there are principles in common between social media and KS [14]. Social Media has shown a positive role in KS. Some researchers have successfully identified the benefits obtained through the use of social media in KS [17]. However, although the principle believed social media synergy with KS but researchers also found the constraints faced in the implementation of social media in KS [18]. KS in social media can be achieved through a variety of tools that allows for creating, codify, organize, and share knowledge, but also to socialize and improve personal network and collaborate in order to organize and create new knowledge [14].

Razmerita et al., 2009, proposes multiple technologies in social media that can be used in optimizing knowledge sharing, namely:

- Personal webpages is a tool that can improve the organization and presentation of information and sharing with the community.

- Personlaized search tools provide the facility to search for and share information.

- Social bookmarking tool that allows community members to share bookmarks of interest among the members.

- Pesonalized live discussion forum is a tool that can guide in analyzing, evaluating, displaying and sharing information among members komuintas.

- Virtual World is a tool that encourages community members to share their knowledge.

- Blogs and wikis are the tools and support for editing, viewing, organizing information or knowledge by individuals or collaborate with others.

The tools in the upper part of the technology and social media services that can be an option for us in optimizing the activity of individual among share knowledge with fellow community members. Unlike the traditional tools for knowledge sharing, social media-based technology services supporting the process of interaction, collaboration more interactive and intensive, thus enabling the sharing of knowledge that is richer in content and more intensive. Social media with all its feature has give a big opportunity to be use as effective KS tool. However in the context of Indonesia people, we do not know yet how success social media play a role as effective tool for knowledge sharing. Through this study we woukd like to investigate how successf of social media utilization in the exchange of knowledge among user who uses social media in Indonesia.

To achive the research objective we need to develop appropriate instrument.This study uses the IS Success Model of DeLone and McLean (2001) as the basic concept to develop research model and instrument IS Success. This article is one part of our complete research. In this study we focus discuss on the process on content validation for our instrument. The validate instrument is critifal aspect in information system research.

\section{RESEARCH METHOD}

Content validity activity is one of the activities which is carried out by observing all item (indicator) contained in the instruments that have been developed are indicators that created has represented and relevant to the topic of the research activities of this validation is generally suitable for the research development of a new instrument to be applied to research [19]. Some opinions from experts related to the validation of content are as follows:

(1) The level where an instrument developed items (indicators) are suitable for measuring constructs / variables measured. [19]

(2) Can whether or not an item (indicator) in a research instrument presented the domain of content aimed at a study [20]

Content Validation can be carried out through the evaluation conducted by a team of experts to the instrument that has been developed. In this activity, the team of experts will evaluate the relevance of indicators selected by the variables measured. The matrix was developing base on the research model. In develop research model Delone and Mclean Success Model applied as basis theory. Delone and Mclean IS 
Success Model was enhanced by consider important factors in social media and knowledge sharing that we found from literature review activities. Figure 1 describes our research model.

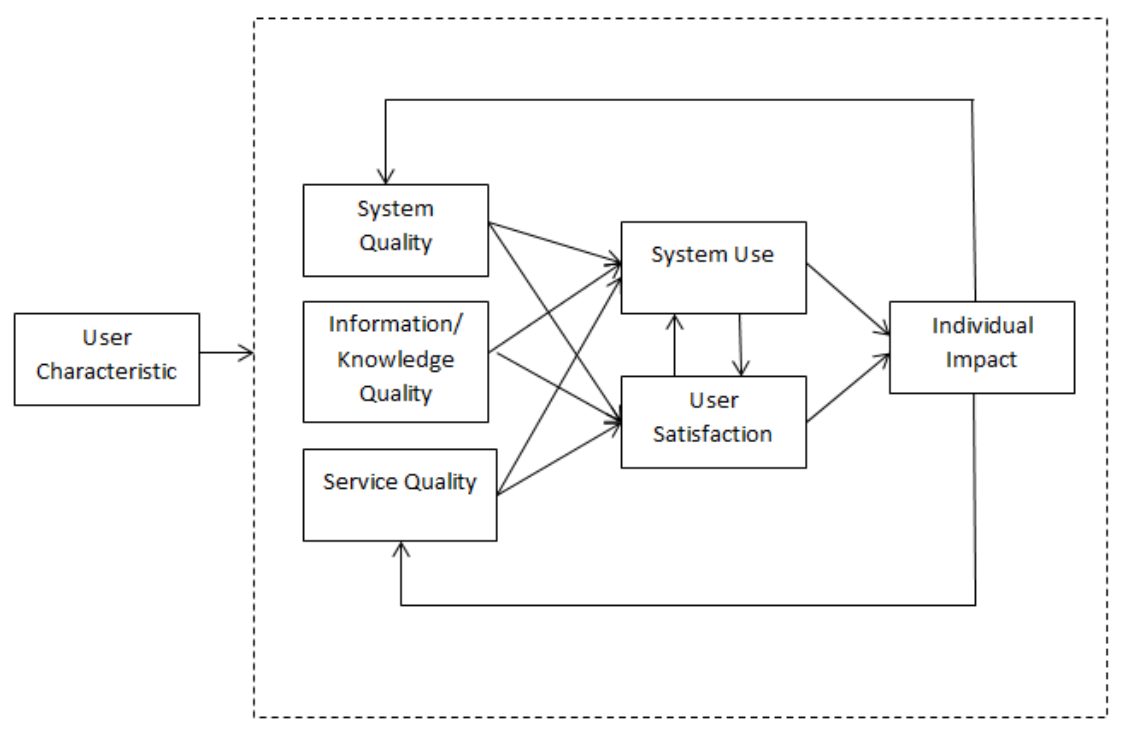

Figure 1. Research Model

After develop the model (Figure 1), we do conceptualization of all variable in corporate with our research model. The conceptualization is important proses, because variable will be specifies define to fulfill the need of the research.

Table 1. Variable Definition and Resources

\begin{tabular}{|c|c|c|}
\hline Variable & Definition & Sources \\
\hline System Quality & $\begin{array}{l}\text { Desirable characteristics of an Information System } \\
\text { quality. }\end{array}$ & [21] \\
\hline $\begin{array}{l}\text { Knowledge/Informa } \\
\text { tion Quality }\end{array}$ & $\begin{array}{l}\text { Desirable characteristics of the system outputs } \\
\text { (knowledge or information) }\end{array}$ & [22] \\
\hline Services Quality & $\begin{array}{l}\text { Quality of the service or support that system users } \\
\text { receive from the IS organization and IT } \\
\text { Support personnel in general or for specific IS. }\end{array}$ & {$[23],[24]$} \\
\hline System Use & $\begin{array}{l}\text { Degree and manner in which staff and customers utilize } \\
\text { the capabilities of an IS. }\end{array}$ & [25] \\
\hline User Satisfaction & Users' level of satisfaction with the IS. & {$[23],[24]$} \\
\hline Individual Impact & $\begin{array}{l}\text { Extent to which IS are contributing to the success of } \\
\text { individuals }\end{array}$ & [21] \\
\hline User Characteristics & $\begin{array}{l}\text { The characteristics of user who using the system. } \\
\text { Understand the user characteristic would help guide } \\
\text { decision about the functionality, design and content to } \\
\text { include on the system. }\end{array}$ & {$[23],[24]$} \\
\hline
\end{tabular}

After the conceptualization prose is finished, a matrix for rater was developing. The next tables describe our matrix for rater.

Table 2 describes tweleve indicators that we develop to measure System Quality Variable. The indicators were adopted from previous research. 
Table 2. Indiactors Statements for System Quality Variable

\begin{tabular}{l} 
Indicators \\
\hline SMQ1: Social media application should be easy to use $\quad$ (Ease of Use) \\
SMQ2: Social media application should be easy to learn $\quad$ (Ease of learning) \\
SMQ3: Social media should be easily accessible application (Access) \\
SMQ4: Social media application should be able to meet the needs of users (User \\
Requirement) \\
SMQ5: Social media application must have features that support information sharing \\
activity (System Feature) \\
SMQ6: Social media application must be supported by a system that is accurate (System \\
Accuracy) \\
SMQ7: Social media application should be accessible on various devices (Flexibility) \\
Social media should be reliable application (Reliability) \\
SMQ8: Social media application should be efficient when used (Efficiency) \\
SMQ9: Social media application should be effective when used (Effective) \\
SMQ10: Social media application should be able to satisfy user (Sophistication) \\
SMQ11: Social media application must be integrated with other applications that support \\
(Integration) \\
SMQ12: Social media application should be customized (Customization)
\end{tabular}

Table 3 describes thirteen indicators that we develop to measure System Quality Variable. The indicators were adopted from previous research.

Table 3. Indicators Statements for Knowledge/Information Quality Variable

\begin{tabular}{l}
\hline \multicolumn{1}{c}{ Indicators } \\
\hline KI1: Information / knowledge is delivered in social media must be reliable (Believability) \\
KI2: Information / knowledge is delivered in social media must be objective (Objectivity) \\
KI3: Information / knowledge is delivered in social media should be accurate (Accuracy) \\
KI4: Information/knowledge presented in social media should be reputable (Reputation) \\
KI5: Information/knowledge presented in social media should have the value of benefits \\
(Value-added) \\
KI6: Information/knowledge presented in social media should be relevant (Relevancy) \\
KI7: Information/knowledge presented in social media should be on schedule needs \\
(Timelines) \\
KI8: Information/knowledge presented in social media should be intact (Completeness) \\
KI9: Information/knowledge presented in social media should be packaged in \\
small amounts of relative data (Appropriate amount of data) \\
KI10: Information / knowledge is delivered in social media should be interpreted properly \\
(Interpretability) \\
KI11: Information / knowledge is delivered in social media should be easily understood \\
(Ease of Understanding) \\
KI12: Information / knowledge is delivered in social media should be presented \\
consistently (Representational consistency) \\
KI13: Information / knowledge is delivered in social media should be exposed briefly \\
(Concise Representation)
\end{tabular}

Table 4 describes five indicators that we develop to measure System Quality Variable. The indicators were adopted from previous research.

Table 4. Indicators Statements for Service Quality Variable

\begin{tabular}{l}
\hline \multicolumn{1}{c}{ Indicators } \\
\hline SQ1: Social media application should have a fast response when used (Responsiveness)
\end{tabular}

Table 5 describes three indicators that we develop to measure System Quality Variable. The indicators were adopted from previous research. 
Table 5. Indicators Statement for System Use Variable

\begin{tabular}{lrr}
\hline \multicolumn{1}{c}{ Indicators } & Not Relevant & Highly Relevant \\
\hline SU1: I use social media to communicate knowledge and information (Communicate & \\
Knowledge and Information) & \\
SU2: I use social media to share knowledge and general information (Share General & \\
Knowledge and Information) & \\
SU3: I will use social media to share specific knowledge and information; (Share & \\
Specific Knowledge and Information) & \\
\hline
\end{tabular}

Table 6 describes three indicators that we develop to measure System Quality Variable. The indicators were adopted from previous research.

Table 6. Indicators Statements for User Satisfaction Variable

\begin{tabular}{l}
\multicolumn{1}{c}{ Indicator } \\
\hline US1: I am satisfied with the Social media application that I use (general satisfaction) \\
US2: I am satisfied with the knowledge and information I got \\
(knowledge/information satisfaction) \\
US3: I am satisfied with the features available on Social media application (System \\
feature satisfaction)
\end{tabular}

Table 7 describes four indicators that we develop to measure System Quality Variable. The indicators were adopted from previous research

Table 7. Indicators Statement for Individual Impact Variable

\begin{tabular}{lc}
\hline \multicolumn{1}{c}{ Indicators } & Not Relevant \\
\hline II1: Social Media is one of my forums in learning (Learning) & \\
II2: Social Media increases my awareness on certain issues (Awareness/ Recall) & \\
II3: Utilizing social media to make decisions which I take to be more effective in & \\
working (Decision Effectiveness) & \\
II4: Utilizing social media makes me productive at work (Individual Productivity) & \\
\hline
\end{tabular}

Activity in determining the relevance of these can be done by several methods. Here is a method that can be selected in carrying out an activity content validation.

(1) Using the average value calculated from the value of relevance score level indicator in the instrument assessed by expert teams [26]

(2) Using alpha coefficient value to measure the suitability of an indicator of the level of relevance denmgan variables [20]

(3) In calculating the value koovariat of kappa coefficient [19]

In this activity, we have a method that is quite a lot has been adopted by previous researchers. This method is a method to calculate the average value of the assessment team of experts (method no. 1). In this method a few people will be designated as a member of the expert team. The expert team is persons who has knowledge relevant to the research topic and have good skills in similar research. The research instrument then collated by listing all the questions of the research instrument along with the column values that represent the level of relevance of indicators (represented by the question as / statement) and the measured variables.

\section{RESULTS AND ANALYSIS}

In this study, the team invited three experts to evaluate the indicators in each variable in the instrument that has been developed. Selection of the team of experts based on the following criteria: Doctorate level education in Computer Science, have experience conducting research in the field of Information Systems, has a good track record international publication.

A matrix was developed as a means for experts to pass rating against indicators that have been created for each variable. Matrix is based on the variables used in this study. The items are grouped based on the variables measured and then a team of experts asked to assess the level of relevance based on the knowledge and experience they have. As a reference in a four-point rating is used by adopting Linkert scale ratings as follows: point 1 = Very irrelevant; point 2 = not relevant; 3 = relevant points; 4 = very relevant points. 
After a team of experts conduct the validation, then performed statistical analysis activities using the ACP (Beck and Gable, 2001). The results of the calculation of the value is from the analysis using method ACP then showed that of the 43 indicators derived from seven variables, the 37 ACP indicator has a value of $100 \%$, and 6 indicators has a value of ACP 90\%. Referring to the opinion of Polit and Beck (2007) that indicator has a value of at least $90 \%$ will be declared acceptable. It can be concluded that all indicators were 42 declared acceptable and can be used for the validation process further.

Validity process is one of important stage in information system research [27], the aim of this activity is to ensure the research instrument meet the information system standart requirment [27],[28]. Scholar from information system area recommended that researcher in information system consistent in conduct all progress to achieve hight quality research in Information system area [27]-[29]. Content validity as one of instrument validity process is being important activity in Information System research area[27].

\section{CONCLUSION}

Result of this study is the instrument which has validate by content validity process. Our next agenda is to do pilot study in order to ensure the instrument meet the criteria in validity and reliability test.

\section{ACKNOWLEDGEMENTS}

The research is supported by Menristek DIKTI by Program Hibah Komptesisi bacth Fundamental Research Tahun Anggaran 2016.

\section{REFERENCES}

[1] H. H. Chang and S. S. Chuang, "Social capital and individual motivations on knowledge sharing: Participant involvement as a moderator,” Information \& Management, vol. 48, pp. 9-18, 2011.

[2] T. H. Davenport and L. Prusak, "Working knowledge: Managing what your organization knows," Harvard Business School Press, Boston, MA, 1998.

[3] T. H. Davenport and L. Prusak, "Working Knowledge: How Organizations Manage What They Know (Paperback),” pp. 224, 2000.

[4] I. Nonaka, "A Dynamic Theory of Organizational Knowledge Creation,” Organization Science, vol/issue: 5(1), pp. 14-37, 1994.

[5] I. Nonaka and H. Takeuchi, "The knowledge-creating company: How Japanese companies create the dynamics of innovation,” Oxford University Press, USA, 1995.

[6] D. Hislop, "Knowledge management in organizations: A critical introduction, Oxford University Press, 2013.

[7] P. Bharati, et al., "Better knowledge with social media? Exploring the roles of social capital and organizational knowledge management,” Journal of Knowledge Management, vol. 19, pp. 456-475, 2015.

[8] A. Y. Chua and S. Banerjee, "Customer knowledge management via social media: the case of Starbucks," Journal of Knowledge Management, vol. 17, pp. 237-249, 2013.

[9] C. Evans, et al., "Overcoming cross-cultural barriers to knowledge management using social media," Journal of Enterprise Information Management, vol. 27, pp. 45-55, 2014.

[10] C. Baehr and K. A. Brown, "Assessing the value of corporate blogs: A social capital perspective,” Professional Communication, IEEE Transactions on, vol. 53, pp. 358-369, 2010.

[11] R. Hanna, et al., "We're all connected: The power of the social media ecosystem," Business Horizons, vol. 54, pp. 265-273, 2011.

[12] A. M. Kaplan and M. Haenlein, "Users of the world, unite! The challenges and opportunities of Social Media," Business horizons, vol. 53, pp. 59-68, 2010.

[13] A. Majchrzak, et al., "Technology Adaptation: The Case of a Computer-Supported Inter-Organizational Virtual Team,” MIS quarterly, vol. 24, 2000.

[14] L. Razmerita, et al., "Personal knowledge management: The role of Web 2.0 tools for managing knowledge at individual and organisational levels,” Online Information Review, vol. 33, pp. 1021-1039, 2009.

[15] G. V. Krogh, "How does social software change knowledge management? Toward a strategic research agenda," The Journal of Strategic Information Systems, vol. 21, pp. 154-164, 2012.

[16] D. Yates and S. Paquette, "Emergency knowledge management and social media technologies: A case study of the 2010 Haitian earthquake,” International Journal of Information Management, vol. 31, pp. 6-13, 2011.

[17] S. Paroutis and A. A. Saleh, "Determinants of knowledge sharing using Web 2.0 technologies," Journal of Knowledge Management, vol. 13, pp. 52-63, 2009.

[18] M. J. Culnan, et al., "How Large US Companies Can Use Twitter and Other Social Media to Gain Business Value," MIS Quarterly Executive, vol. 9, 2010.

[19] D. F. Polit and C. T. Beck, “The content validity index: are you sure you know what's being reported? Critique and recommendations,” Research in nursing \& health, vol. 29, pp. 489-497, 2006.

[20] C. F. Waltz, et al., "Measurement in nursing and health research,” Springer Publishing Company, 2010. 
[21] G. G. Gable, et al., "Re-conceptualizing information system success: the IS-impact measurement model,” Journal of the association for information systems, vol. 9, pp. 377, 2008.

[22] U. R. Kulkarni, et al., "A knowledge management success model: Theoretical development and empirical validation,” Journal of management information systems, vol. 23, pp. 309-347, 2006.

[23] W. H. Delone and E. R. McLean, "The DeLone and McLean model of information systems success: a ten-year update,” Journal of management information systems, vol. 19, pp. 9-30, 2003.

[24] S. Petter, et al., "Information Systems Success: the quest for the independent variables," Journal of Management Information Systems, vol. 29, pp. 7-62, 2013.

[25] J. H. Wu and Y. M. Wang, "Measuring KMS success: A respecification of the DeLone and McLean's model," Information \& Management, vol. 43, pp. 728-739, 2006.

[26] C. T. Beck and R. K. Gable, "Ensuring content validity: An illustration of the process," Journal of nursing measurement, vol. 9, pp. 201-215, 2001.

[27] M. C. Boudreau, et al., "Validation in information systems research: a state-of-the-art assessment," Mis Quarterly, pp. 1-16, 2001.

[28] S. B. MacKenzie, et al., "Construct measurement and validation procedures in MIS and behavioral research: Integrating new and existing techniques,” MIS quarterly, vol. 35, pp. 293-334, 2011.

[29] N. Urbach and F. Ahlemann, "Structural equation modeling in information systems research using partial least squares,” JITTA: Journal of Information Technology Theory and Application, vol. 11, pp. 5, 2010.

\section{BIOGRAPHIES OF AUTHORS}
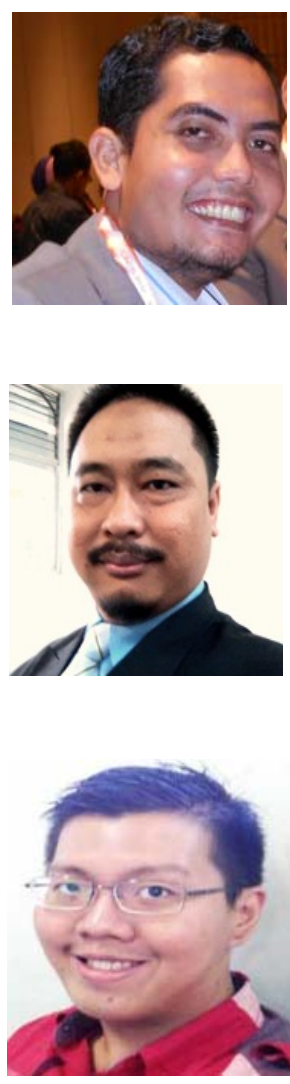

Setiawan Assegaff was born in T.Karang, Indonesia. He is PhD Information System holder from Universiti Teknologi Malaysia. His special fields of interest included Knowledge Management, Social Media, Technology Adoption and Social-Commerce. He has experiences as lecture for more then tweleve years. His works have been published in national and international journal and conferences.

Kurniabudi was born in Jambi, Indonesia. He received degree from UPI YPTK Padang and master degree in Magister of Information Technology from same university. His current research interests include E-Learning, Information system, and Technology Adoption.

Hendri was born in Jambi, Indonesia. He received degree from STIKOM Dinamika Bangsa Jambi in 2009 and master degree in Magister information system from STIKOM DB of Jambi in 2011. His current research interests include Web Development, database, Information system, Online Marketing, E-commerce, E-Business. 